\title{
Helping Ma and Helping Pa: Iowa's Turn-of-the-Century Farm Children
}

\section{PAMELA RINEY-KEHRBERG}

IN THE HALF-CENTURY following the Civil War, the United States entered a period of rapid urbanization. The nation that had its origins on the farm was moving to the city. Although this process was more apparent and more rapid in states such as Massachusetts and New York, it was under way even in the agricultural heartland, in states such as Iowa. Between 1880 and 1900 , Iowa's population grew by nearly 40 percent, but its cities over 8,000 in population increased by nearly 250 percent. By 1900, agricultural occupations employed less than 50 percent of the work force. ${ }^{1}$ Although Iowa would remain, in many ways, a farm state, it shared in the demographic change common to an urbanizing nation.

As Americans moved from the countryside to the cities, many facets of their lives changed, including their family lives. In the transition from rural to urban, the United States was at a turning point between old and new definitions of childhood. Older rural traditions demanded that children play an impor-

1. Carroll Engelhardt, "Compulsory Education in Iowa, 1872-1919," Annals of Iowa 49 (1987), 66.

I would like to thank the State Historical Society of Iowa for the historical research grant that made this article possible, and Micheline Turner for graciously allowing me to live at her home in Coralville while I worked. I would also like to thank Marvin Bergman and three anonymous reviewers for their extremely helpful comments.

THE ANNALS OF IOWA 59 (Spring 2000). (C) The State Historical Society of Iowa, 2000. 
tant role in the economic life of the family. While turn-of-thecentury reformers and many middle-class urbanites asserted that children should be playing and learning rather than working, conditions in rural communities dictated that older definitions would prevail. Most American agricultural enterprises at the turn of the century were family farms. That term implied, even demanded, that all members of the family work. In spite of the forces of change spreading throughout the nation, Iowa's farm children grew up in an economic and social system that both required and placed a high value on children's usefulness. ${ }^{3}$

Iowa's farm-raised youngsters, like those all across the country, lived lives that in some ways conformed to, but in many ways deviated from, the urban ideals of their day. Work was generally the cornerstone of their lives, and other activities, such as school and recreation, often played a secondary role. Needing their children's labor, farm parents valued hard work and taught their children to be useful. They were educating their children for their future roles as farm owners and farm laborers, whether those children were boys who would work in the fields or girls who might work in the fields or in the home. ${ }^{4}$

This emphasis on work did not suit the purposes of an increasingly middle-class and urban America, which was coming to think of children as economically useless but emotionally priceless. $^{5}$ At the turn of the century, however, the ideal of the useless child applied to only a minority of American youngsters.

2. The term childhood cannot be defined precisely in the context of late nineteenth-century rural communities. The term teenager had not yet been invented, and many youngsters well into their teens and early twenties, though physically adults and no longer in school, remained at home, working for their parents. In that context, a child is best defined as any dependent son or daughter, regardless of physical maturity, who remained subject to his or her parents' authority on the farm and within the home.

3. One of the best descriptions of usefulness as a value in the context of rural communities is in Claire Toynbee, Her Work and His: Family, Kin, and Community in New Zealand, 1900-1930 (Wellington, New Zealand, 1995).

4. Mary Neth, Preserving the Family Farm: Women, Community, and the Foundations of Agribusiness in the Midwest, 1900-1940 (Baltimore, 1995), 20-25; Sonya Salamon, Prairie Patrimony: Family, Farming, and Community in the Midwest (Chapel Hill, NC, 1992), 52-53.

5. See Viviana Zelizer, Pricing the Priceless Child: The Changing Social Value of Children (Princeton, NJ, 1994), 3. 
Farm children (as well as urban working-class children) remained useful and an economic asset long after middle-class urban children became a serious drain on their parents' assets. Some scholars have observed this fact and argued that late nineteenth- and early twentieth-century farm childhood was unduly harsh and damaging to those children who lived them, but this conclusion bears further evaluation. ${ }^{6}$

The lives of Iowa's farm children must be examined in relationship to the larger circumstances of turn-of-the-century American childlife. While middle-class urban children might have lived lives of leisure, that was certainly not true of the children of the urban working classes and poor. In the first decades of the twentieth century, poor urban children would gradually join the ranks of the "useless" child as child labor laws began to limit their ability to earn. Even so, their place in the ranks was tenuous, as the Great Depression forced even some middle-class children to become useful. ' On the other hand, many farm children across the country fared worse, on the whole, than farm children in Iowa and the Midwest. Those in the South suffered far worse conditions and far higher levels of poverty, malnutrition, and child mortality. ${ }^{8}$ In Iowa's rural communities, infant mortality was comparatively low and life expectancy was high.' Most parents fed, housed, and clothed their children adequately, if not lavishly or fashionably. ${ }^{10}$ Iowa's turn-of-the-century farm

6. Elizabeth Hampsten, Settlers' Children: Growing Up on the Great Plains (Norman, OK, 1991); Liahna Babener, "Bitter Nostalgia: Recollections of Childhood on the Midwestern Frontier," in Elliott West and Paula Petrik, eds., Small Worlds: Children and Adolescents in America, 1850-1950 (Lawrence, KS, 1992), 302.

7. Zelizer, Pricing the Priceless Child, 5-6.

8. See, for example, Charles E. Gibbons and Clara B. Armentrout, Child Labor among the Cotton Growers of Texas: A Study of Children Living in Rural Communities in Six Counties in Texas (New York, 1925), 34-46, 70-111.

9. A study of the conditions of childlife on Iowa's farms, researched in the 1920 s and published in 1930, revealed that farm children in Iowa were relatively healthy. Mothers had fairly good maternity care, babies had relatively high birth weight, and children exhibited normal levels of health and well being. Bird T. Baldwin, Eva Abigail Fillmore, and Lora Hadley, Farm Children: An Investigation of Rural Child Life in Selected Areas of Iowa (New York, 1930), 181, 184-85, 297.

10. A 1926 U.S. Department of Agriculture survey of the standard of living in farm communities in eleven states determined that Iowa's farm families, on 
children lived reasonably secure lives, but at the cost of the era's newly ascendant middle-class and urban ideals, which valued school and leisure over long hours of work.

The years between 1870 and 1920 were a time between two great periods of stress and change: after the Civil War but before the technological changes that altered farm life in the twenties and beyond. During these fifty years, corn and livestock production, as well as dairying, experienced relatively few changes that would have altered significantly the patterns of daily life for farm children, and most of Iowa's farms remained family farms, highly dependent on family labor. Children's participation in the family economy remained vital. That is not to say that this era was without change. These years were marked by both economic distress and relative prosperity, both of which affected the quality of childlife. Also during this period, attitudes about the inappropriateness of child labor strengthened within America's middle-class urban elites, leading to legal change. These years saw the advent of Iowa's first child labor and compulsory schooling laws. While child labor laws had little, if any, impact on farm children, compulsory education laws had the potential to alter greatly a child's relationship to his or her parents' farm. This struggle over children's time would, in fact, continue well into the 1940s and even 1950s, but the foundation for this conflict was laid by the turn of the century.

Examining the contours of childlife during this period requires a certain amount of creativity on the part of the researcher. Farm children and adolescents did write letters and diaries describing their lives; unfortunately, these sources are rare. Small children generally did not leave many records, and older children were often too busy or may not have had sufficient skills to leave extensive written records of their activities. Some parents left writings describing their children's work, play, and

average, expended a relatively high amount of money on clothing, health care, and "advancement" (books, newspapers, and educational materials). Iowa families spent $\$ 242.50$ annually on clothing, more than the average in the northeastern, north central, and southern states. They also spent $\$ 85$ on health care, the highest among all the study areas, and $\$ 108$ on advancement, a sum, on average, exceeded only by New England. E. L. Kirkpatrick, The Farmer's Standard of Living: A Socio-Economic Study of 2,886 White Farm Families of Selected Localities in 11 States, USDA Bulletin No. 1466 (Washington, DC, 1926), 16. 
education, but most did not. Historians are forced to rely, at least occasionally, on memoirs, autobiographies, and reminiscences about rural childhood written many years or even decades after the events they describe. There are dangers, of course, in the use of such sources. As historian James Marten has commented in his study of Civil War children, "People spread happy memories like a quilt of nostalgia over the past and difficult or even horrifying recollections to support their perceptions of themselves as tough survivors." Individuals' interpretations of their childhood experiences may indeed be suspect, and may, over time, take on a rosy glow that they as children would not have recognized. However, as Marten also asserts, the events related in memoirs can be weighed against other existing information and judged to be reliable or not based on that comparison. In other words, memoirs of childhood should never be examined without reference to a larger body of historical evidence. When studying the lives of historical actors who left very few records, the researcher must judiciously use whatever sources may be available."

The resources available to historians reveal a diversity of experience among Iowa's turn-of-the-century farm children. As urban middle-class ideals about childhood infiltrated the countryside, farm families expressed ambivalence about the proper balance among their children's work, recreational, and educational activities. In Iowa, however, even reformers tended to agree that farm life, and its attendant labors, built character among those children who experienced it.

FROM AN EARLY AGE, farm children learned responsibility and prepared for the more advanced tasks that came with greater age and ability. Infants and toddlers required time and effort from parents and siblings, but parents quickly trained small children to be industrious. Children as young as four and five could be asked to carry out small chores. They helped their

11. James Marten, The Children's Civil War (Chapel Hill, NC, 1998), 27-28. Liahna Babener has argued that the memoirs of farm-raised midwesterners have an underlying bitterness and disillusionment that even the writers do not consciously recognize. Babener, "Bitter Nostalgia," 301-20. 


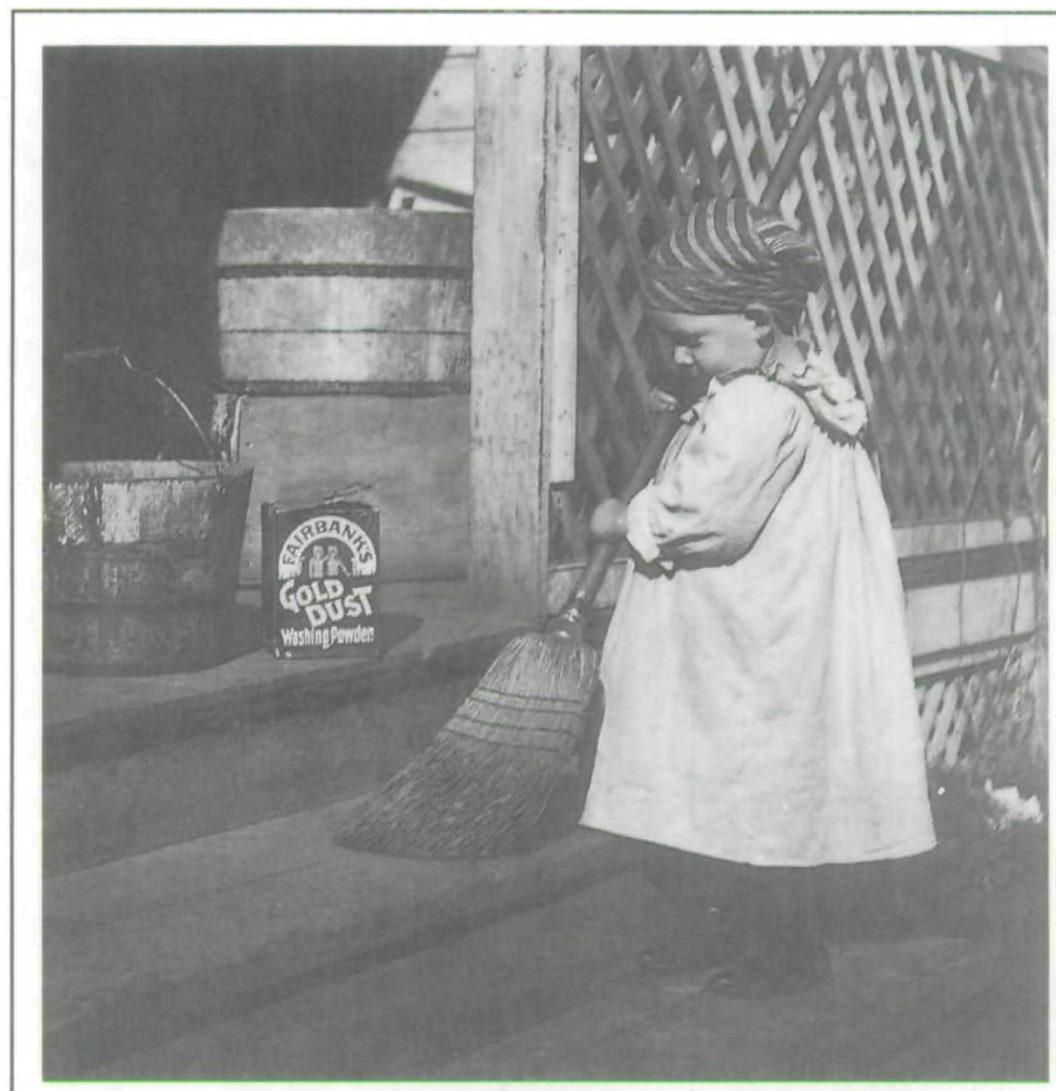

Even very small children could make themselves useful. Photo courtesy State Historical Society of Iowa, Iowa City (Foster Collection).

mothers both inside and outside the house. Parents often expected small children to amuse their younger siblings, fetch wood and kindling, dry dishes, and carry out other limited tasks. ${ }^{12}$ David Bruce Dill, raised by an aunt and uncle on their Louisa County farm, described the kind of work that might be assigned to a five-year-old child. "I was given indoor 'chores,' drying dishes, keeping the wood-box and water bucket filled and in winter the coal bucket filled with anthracite. Outdoor

12. Elliott West documented a child less than three years old fetching, carrying, and generally being useful to his farming parents. Elliott West, Growing Up with the Country: Childhood on the Far Western Frontier (Albuquerque, NM, 1989), 75. 
there were eggs to gather and chickens to feed. ${ }^{\prime \prime 3}$ The demands of a working childhood began early.

As children matured, they were absolutely integral to the continuation of their parents' farms. Diaries written by both parents and children illustrate the important role Iowa's youngsters played in their parents' enterprises. John M. Inman of Eden Township in Benton County was the father of four sons. In 1870 at least two of those sons were teenagers, but none of the Inman boys was over the age of 16 . Nonetheless, they were active participants in the economic life of the Inman farm. The oldest Inman sons, George and John, regularly appear in their father's diary cutting and hauling wood, butchering, cleaning, hauling manure, plowing, planting, haying, harvesting, and threshing. Even the paid labor that the young Inmans performed enriched the family coffers. When the boys threshed for neighbors, the pay went to their father rather than to them. This was in keeping with family law, which awarded the profits of the labors of children under the age of 21 to their parents. The threshing was not pure profit for John Inman; the boys broke the threshing machine two days running. While Inman went to town to buy replacement parts, he assigned his sons one of the most unpleasant tasks on a farm. On September 14, 1870, Inman wrote in his usual terse style, "Boys hall manure." When the elder John Inman was away from the farm attending meetings in town, the boys were responsible for all of the fieldwork. Only the rare treat interrupted the flow of labor. On October 24, John Inman recorded, "Boys went to Circus in evening." The Inman sons spent the vast majority of their time working for their father, and their labor contributed significantly to the family farm. ${ }^{14}$

Not all sons worked for their fathers under the same unrewarding and arduous terms as the Inman boys. In 1872 Oliver Perry Myers was also a teenager working on his father's farm in Washington County. It is clear that he was an active participant in the family economy, but his relationship to his father and the family farm was rather different than that of the Inman boys.

13. David Bruce Dill, "Boy Life on the Farm, Wyman, Iowa, 1896-1903," typescript memoir, State Historical Society of Iowa, Iowa City, Iowa (hereafter SHSI).

14. John M. Inman, manuscript diary, 12-14 September and 24 October 1870, SHSI. 
Oliver Myers planted, plowed, and harvested crops, hauled manure, dug drains, set out trees, and generally made himself useful to his parents. But he also worked for himself. He owned his own livestock and sometimes sold and traded animals with his father, who also gave him his own fruit trees to plant and tend. He trapped prairie chickens for sale. When he hired out his labor to neighbors, his father, unlike John Inman, allowed him to keep his earnings. Oliver Myers was not only a participant in the family enterprise; he was also a young entrepreneur. On July 31, 1872, he wrote, "I have Earned \$7.25 this harvest working from home I made a hand all this harvest. . . . I had a small patch of oats this year. I got 23 shocks on it. My hogs are doing fine though all the pigs died. ${ }^{\prime \prime 15}$ One of the best indications of the differences between the upbringings of Oliver Myers and the Inman boys is that Myers regularly attended school and eventually went on to the University of Iowa, while the Inman boys attended school only rarely and sporadically. Neither diary addresses whether this difference was simply a matter of parental style or was caused by differing economic situations. But evidence from the 1870 Census seems to indicate that, given the economic similarities between the Inman and Myers farms, the Inmans' attitude about the importance of work, rather than economic necessity, was the deciding factor.

Girls experienced a somewhat different pattern of work. By the time they entered their teens, most girls spent more time working inside the house than outside, although most spent some time working in the fields. In 1872 and 1873, Sadie Stilson, age 14, recorded her work and play in a diary. Stilson's work inside the home consisted of helping her mother cook and bake, churn, iron, wash, sew, and do other housekeeping chores. Her work, however, was not confined within the bounds of the household. When needed, she participated in crop production by husking and shelling corn, although her brother Jay was far more active in such occupations. The Stilson family was apparently relatively well-to-do, because Jay Stilson was able to attend school in Cedar Rapids, and Sadie Stilson found plenty of

15. Oliver Perry Myers, manuscript diaries, 1872-1874, Oliver Perry Myers Papers, SHSI. 


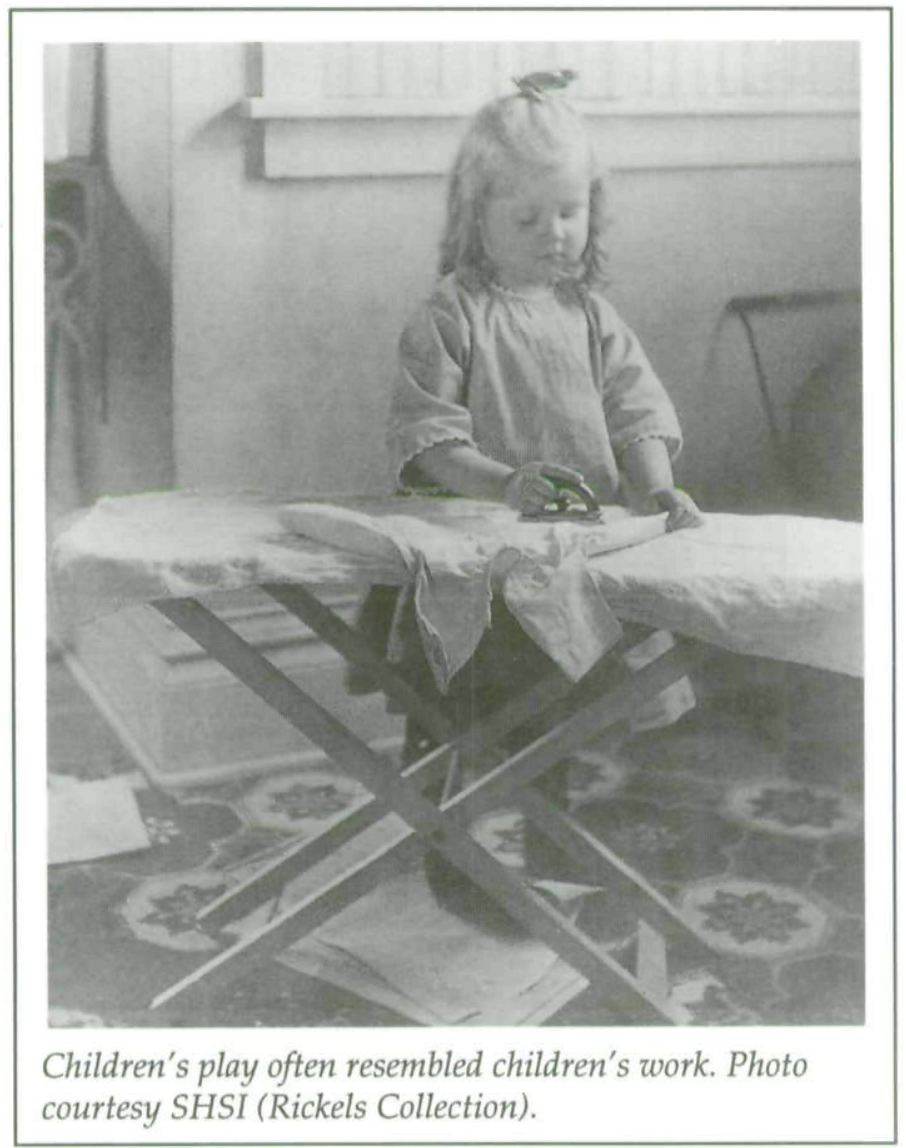

time for pleasant diversions such as croquet. On April 25, 1873, Sadie wrote, "we played Croquet ma Ironed."16 That Sadie and her friends played while her mother worked is significant. More commonly, a teenaged daughter would have assisted her mother in completing the work before taking time for amusement. The Stilsons evidently valued amusement as well as work for their children, and were able to spare their labors to the occasional afternoon of games.

Mary Eleanor Armstrong, growing up in Jones County, experienced a similar working childhood. Armstrong was born

16. Sadie and John J. Stilson, manuscript diaries, 1870-1878, SHSI. 
in 1875 and began her diary just before her sixteenth birthday. She, too, worked more inside the home than outside. Like Sadie Stilson, Armstrong cooked and baked, sewed, and generally tended to housework. She was an avid gardener who raised vegetables as well as a wide variety of flowers, particularly geraniums. She also milked and cared for chickens. The chickens, however, had a specific purpose. She wrote, "I am going to take care of the little chickens this year. I commenced saving eggs to get me a new dress with." Her participation in crop production was generally limited to the corn harvest, when she picked and husked alongside her father and siblings. It could be a daunting task. "I have got a sprained wrist. Pa is sick over corn picking and is pretty well used up. We finished picking corn though. . . my wrist is swelled tonight and is awful lame. ${ }^{\prime 17}$ Working to the point of physical pain was not an unusual situation for farm children, and Armstrong was no exception. School, dances, and boys distracted this youngster from her work, but she was never very far from the duties that bound her to the family farm.

Teenaged sons and daughters played different roles in their parents' farming enterprises. Their roles evolved as they matured. Young children often did the same types of chores, regardless of gender. They might work in the garden, gather wood and corncobs for fires, and herd cattle. ${ }^{18}$ As the years passed, however, boys' and girls' tasks diverged. Boys, by the time they reached adolescence, generally followed their fathers into the fields and rarely did housework. A mother might enlist a son for a particularly heavy household chore. On October 21, 1872, Sadie Stilson wrote, "Jay and Ma washed Quilts." ${ }^{19}$ Wrestling wet quilts out of the washtub required a strong back, and Jay's was available. Girls, however, regularly joined their mothers in most household chores. A young Sarah Gillespie may have described a girl's lot best when she wrote on November 6, 1879, "help ma! help ma!! help ma!!! all day."20 "Helping ma" may

17. Mary Eleanor Armstrong Peet, typescript diary, 18 April 1892 and 19 November 1891, SHSI.

18. West, Growing Up with the Country, 88.

19. Stilson diary, 21 October 1872.

20. Sarah Gillespie Huftalen, manuscript diary, 6 November 1879, SHSI. 


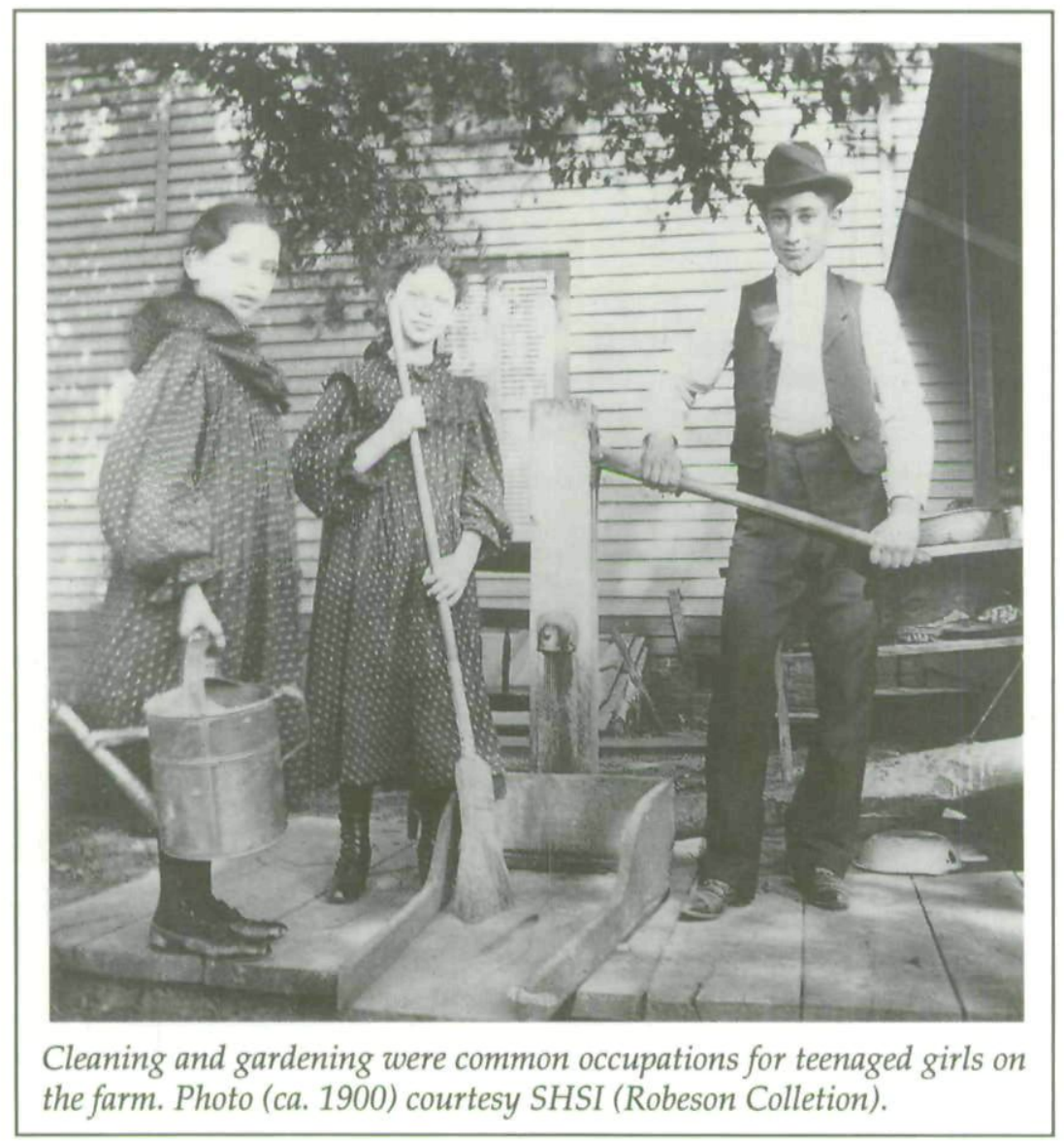

have described most days for most Iowa farm girls, but it did not preclude them from going into the fields when necessary to "help pa." The high labor demands of corn planting and the corn harvest, in particular, took girls into the fields. Beliefs about the proper gendered division of labor tended to crumble in the face of necessity. Ethnicity shaped attitudes about proper work for girls, with young women of German, eastern European, or Scandinavian descent more likely to work in the fields than their native-born counterparts. ${ }^{21}$

21. Neth, Preserving the Family Farm, 21, 25. 
Some girls would have preferred to work outside on a regular basis, rather than remain in the house with the other females. In her memoirs, Mollie Krutza wrote, "I liked better to work out-doors; carrying water to men in the fields, bringing the cows in from the pasture in the evening, turning the calves out of their pen to get their suppers." Krutza's father, however, believed that his daughters should work indoors. "Although the girls worked hard, Father never wanted them to do heavy farm work. In fact, they were so busy around the house and garden that they did not go into the fields often. ${ }^{\prime 22}$ In Krutza's family, need coincided with ideology; their father did not approve of fieldwork for girls, and the family generated enough household chores to employ all of the family's daughters. If the family had greatly needed its daughters outdoors, it is likely that Mollie's father would have found a way to reconcile his ideals to outdoor labor for females.

NEED often dictated the balance between work, school, and leisure. Work was at the center of farm children's existence. The farm, with its animals, crops, and daily chores, was with them every day. School, be it a half-mile down the road or six, existed at a distance. The distance was greater for some children than for others. Oliver Myers, Sadie and Jay Stilson, and Mary Armstrong attended school regularly, but the Inman boys clearly did not. The Inmans' experience may have been closer to the average Iowa child's experience. Many parents, such as John Inman, believed that work came before school and leisure, and many other families required their children's labor because of poverty, either temporary or persistent. Few families could afford to provide their children ample leisure on a regular basis.

Even in families that valued education, achieving that education could be difficult. Rosa Armentrout, whose family lived near Wilton, grew up to be Dr. Rosa Armentrout Butterfield, but at times she despaired of completing her education. She loved school, writing often in her diary about her fellow students and their daily activities. School was both an academic and a social

22. Mollie Krutza, "Memories of Childhood on an Iowa Farm by Mollie Krutza nee Mary Ellen Harbold Written in 1952," typescript reminiscence, 11, 17, SHSI. 
occasion. In 1877 , shortly before she turned 16 , she wrote, "I am going to school now. ... We have splendid times at school. We play blackman and ring and charades and ball and every thing else almost every day. I study Reading, Grammar, Geography, Physiology, Arithmetic and Writing. ${ }^{123}$ Her love of education, however, could not always overcome the barriers between her and the schoolhouse door.

Like most rural youngsters, Rosa Armentrout found that the forces of nature worked against regular school attendance. Wet weather often rendered dirt roads and farm fields impossibly — and impassibly-muddy. After a night of torrential rain, "the sloughs were so bad that Mother wouldent let me go." The next day, the rain continued, and her disappointment was acute. "Oh how I cried, For the laziness of men, Can never be described. No one knows how bad I wanted to go to school today. I couldent keep from crying, because teacher was going to give me her watch this evening, and I was going to teach for her awhile tomorrow ... but the men were actually too lazy to put the bed on the wagon, so they could take me." The men judged their work to be more important than Rosa's schooling, and she remained at home. Even when the day was bright and she did not need any help to get to school, chores might interfere. Washing was the chief culprit. Rosa wrote, "I did not go to school today. I dident like to stay out but Mother went up to Johns today and I had to stay at home and help wash. I don't like to wash. I know I am pretty lazy but I cant help it." Although a self-proclaimed lazy daughter, Rosa Armentrout often assisted her mother with washing and cleaning, sometimes at the expense of school. ${ }^{24}$

Duty was the most important force working against Rosa's education, and she feared that she might have to sacrifice school to the needs of her family. When her mother became ill in the summer of 1877 , she believed that her opportunity to attend school in Iowa City had been forfeited. "Mother is about the same today," she wrote. "If Mother would be able to spare me I would get to go to school the Fall term in the City, but I know

23. Rosa B. Armentrout, typescript diary, 4 February 1877, SHSI.

24. Armentrout diary, 6 and 7 February and 14 March 1876. 
Ma will not be well enough to do the work although she says she will." When fall came, however, Mrs. Armentrout was sufficiently recovered to allow Rosa to pursue her education. Although she was now free to study "Arithmetic, Analysis, Physiology, History and Penmanship," she still worried about her mother, noting, "I know she is lonesome without me." ${ }^{\text {" Un- }}$ doubtedly Rosa had been her mother's right arm, providing both companionship and invaluable assistance with the many chores required to make a farm home.

One other issue complicated Rosa Armentrout's attempts to further her education; she worked to pay the cost of her own room and board in Iowa City. In the first week of school, she explained her predicament. "It is late now and I am not ready to go to bed yet. My studies alone would not keep me so busy but I have the two rooms upstairs to see too. beds to make. sweep out \& tidy up in general, and help the hired girl with the dishes every noon and night. that is what takes my study time. ${ }^{\prime 26}$ In spite of the work and aggravation that her education cost, Rosa Armentrout was lucky; her parents allowed her to work for her own benefit and her own education. Many farm families preferred or needed their daughters and sons to remain at home to contribute to the support of the entire family.

In many farm families, parents perceived education as a luxury, while work was a necessity. Such parents sacrificed their children's education to the demands of the farm. They may also have believed that farm work was an education in and of itself, preparing their children for a lifetime of labor. In 1889, more than a decade before Iowa passed a compulsory education law, 75 percent of Iowa's school-age children were enrolled in school, but only 47 percent ever actually attended. ${ }^{27}$ May Lacey grew up

25. Ibid., 4 August and 17 September 1877. For more on this tension between the "vague and unformulated" sense of responsibility many young women at this time felt to the world at large and the often more immediate claims of family, see "'Come Home at Once': The 1917 Letters of Neva Stockdale," Iowa Heritage Illustrated 80 (1999), 122-37.

26. Armentrout diary, 19 September 1877.

27. Keach Johnson, "Elementary and Secondary Education in Iowa, 1890-1900: A Time of Awakening," Part I, Annals of Iowa 45 (1979), 103. Iowa's attendance rates actually compared favorably with those in the United States as a whole. In 1900 the U.S. Census Bureau estimated that 48 percent of youngsters five to 
on a Palo Alto County farm, and her brothers were a part of that half of all Iowa children who did not attend school. Lacey wrote, "The children had their work to do as soon as it was possible for them to work. Brother Fred took a man's place from the time he was ten years old and Frank followed suit though he did have a little better chance for schooling since he attended a few spring terms. ${ }^{\prime \prime 2}$ Children in such families might begin school at age seven or eight or older, end their formal schooling long before completing grammar school, and have spotty attendance records due to bad weather, long distances, and the ever present demands of work.

All farm children were susceptible to pressures that might limit their schooling, but boys were especially susceptible. In the spring and fall, many parents kept their sons at home to help with the planting and harvesting. ${ }^{29}$ The records of the North Liberty School in Iowa Township, Cedar County, show a pattern of attendance that was typical of many country schools. In the spring of 1877,39 children attended the school. Of those, only 12 were boys, and only 3 of those boys were over the age of ten. None of the three teenaged boys attended more than 14 days out of a three-month term. On the other hand, 10 girls over the age of ten were enrolled and generally had strong attendance records. During the 1887-88 winter term, 20 males and 12 females attended the school. During the spring, when planting and cultivating were primary concerns, the boys virtually disappeared from school, with 3 males and 17 females attending. The same was true, although to a lesser extent, for the fall corn harvest, when there were 8 males and 15 females. By the beginning of the winter term, the numbers of boys and girls were almost even, 12 boys and 11 girls. In the course of the academic

nine years of age and 80 percent of ten- to fourteen-year-olds were attending school. By that time in Iowa, 67 percent of five-to nine-year-olds and 91 percent of ten- to fourteen-year olds attended school. U.S. Census Office, Twelfth Census of the United States, 1900, vol. 2, pt. 2, Population (Washington, DC, 1902), xcv.

28. E. May Lacey Crowder, "Pioneer Life in Palo Alto County," Iowa Journal of History and Politics 46 (1948), 176.

29. This pattern of attendance, with older boys having high rates of absence in all but the winter term, is described in Paul Theobald, Call School: Rural Education in the Midwest to 1918 (Carbondale, IL, 1995); and Thad Sitton and Milam C. Rowold, Ringing the Children In: Texas Country Schools (College Station, TX, 1987). 


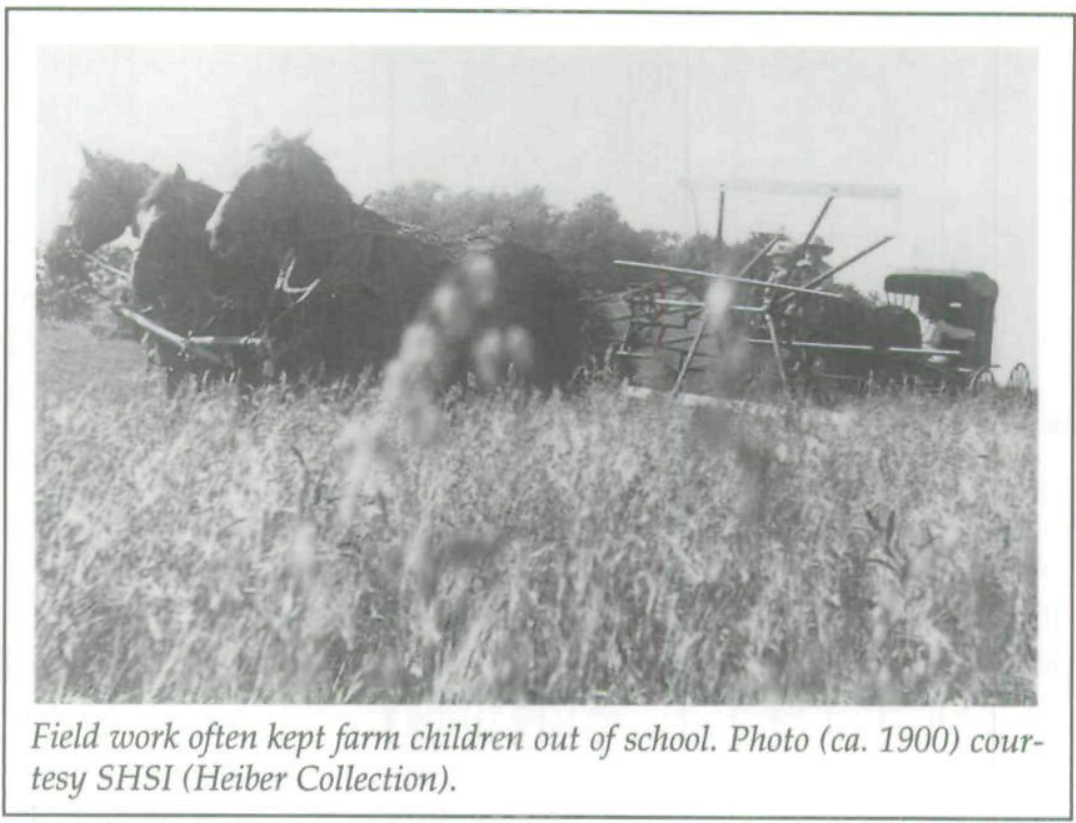

year, only one child, a girl, was neither absent nor tardy. ${ }^{30}$ These deficiencies in the education of rural children, and differences between girls' and boys' attendance rates, eased as the years progressed, partly because of compulsory education laws and changes in the farm economy. At the turn of the century, however, the rural school year remained substantially shorter than in urban areas, reflecting the seasonal demands on child labor. ${ }^{31}$

The demands of farm labor was not the only force working to limit school attendance. Disease, bad weather, distance, and other factors cut into farm children's education. Youngsters writing about themselves to children's publications, such as American Young Folks, described their work, play, and family lives. They also explained the reasons for their lack of schooling. Given the high disease rates of the late nineteenth and early twentieth centuries, it is not surprising that many children lost

30. Teacher's General Register, Spring 1877, and Teacher's Term Reports, 18871891, School District No. 2 (North Liberty School), Iowa Township, Cedar County, Records, SHSI.

31. Johnson, "Elementary and Secondary Education in Iowa," 103-4. 
days, weeks, and even months of school to illness. Ella F. Campbell of Lucas County wrote, "My sister Susie died this winter of diphtheria and lung fever, and I had it very bad at the same time, so that I could not go to the funeral. I am going to school now. I did not go this winter on account of my sickness. ${ }^{132}$ Some children sacrificed school not to their own illnesses, but to the illnesses of others. Young Imogene Sorber of Gowrie explained her situation, which was much like Rosa Armentrout's. "I have been going to school; but it was out yesterday. . . . Ma has been sick, and I have had to stay at home to help her for two weeks. ${ }^{123}$ Other children's families lived too far from schools to attend regularly.

The hit-or-miss nature of school attendance was, of course, contrary to the wishes of middle-class urban reformers who were working to move children more consistently into the classroom. Reformers discovered that this goal was easier to achieve in urban areas. Children working in industrial and service occupations in the cities were relatively visible. Their work took them into the public eye and into public places where authorities felt comfortable intervening. Poor urban children's work was just as important to their families as farm children's work was to theirs, but because urban children usually worked outside the family home, authorities did not have to think of prohibiting that labor as an intervention into the private life of the family. ${ }^{34}$ Stopping child labor on farms was another matter altogether. Intervention meant an intrusion into the home and the family, into what was perceived as thoroughly private space.

Like most states, Iowa's child labor laws addressed the industrial workplace rather than the farm. By 1920, state legislators had placed restrictions on children working in factories, stores, businesses, and service establishments operating during school hours, and had prohibited children from working at

32. "Our Post Office," American Young Folks 6 (May 1880), 77.

33. "What Uncle Frank Says," American Young Folks 2 (July 1876), 52.

34. Elizabeth Pleck has documented the same phenomenon in the prosecution of child abuse. Those parents whose abuse was the most visible-poor urban families-were punished; those whose activities were hidden escaped prosecution. Elizabeth Pleck, Domestic Tyranny: The Makings of Social Policy against Family Violence from Colonial Times to the Present (New York, 1987), 85. 
night, but had provided no protection for children working on their parents' farms. ${ }^{35}$ The author of a 1914 state publication discussing child labor in Iowa essentially dismissed the necessity for such legislation, commenting that "much work in which children are engaged is beneficial - especially that which is performed around the home and in the open air," a definition that encompassed nearly all of farm children's labors. ${ }^{36}$ Instead, legislators generally used laws governing school attendance to attempt to force farm children out of the fields and into the classroom.

In Iowa, mandatory school attendance was a long time in coming. The state did not pass mandatory attendance laws until 1902, and then largely because of concerns for urban, rather than rural, children. In the last two decades of the nineteenth century, Iowa began to urbanize, a situation that caused legislators great concern. Urban youth, apparently truant and idle, were highly visible, and worried legislators in ways that rural children did not, prompting turn-of-the-century lawmakers to grapple with the issue of compulsory school attendance. Legislators appear to have acted out of a fear of delinquency far more than a desire to provide a solid education for all of Iowa's youth. ${ }^{37}$

Not surprisingly, the law, when enacted, was more strictly enforced in urban than rural locations. The school year in most rural locations was substantially shorter than that in urban areas. A report in 1895 estimated the total months of education for urban children at 66 , compared to 26 for children in the country, a combination of a shorter rural academic year and fewer years of education for farm youth. ${ }^{38}$ The law also did not compel attendance for rural children in the same way that it did for those in urban areas, as it only provided for truant officers in cities of 20,000 or more. ${ }^{39}$ Lawmakers appear to have believed that nonattendance, and perhaps the potential for delinquency, was a less important issue in rural communities.

35. U.S. Department of Labor, Children's Bureau, State Child Labor Standards, January 1, 1921 (Washington, DC, 1921), 1.

36. Fred E. Haynes, Child Labor Legislation in Iowa (Iowa City, 1914), 11.

37. Engelhardt, "Compulsory Education in Iowa," 66.

38. Johnson, "Elementary and Secondary Education in Iowa," 109.

39. Engelhardt, "Compulsory Education in Iowa," 71. 
Legislators generally left the enforcement of the law to local authorities, who were reluctant to take their friends and neighbors to court. Sociologist John Gillette, examining this problem in North Dakota, alleged, "I have heard county superintendents advise rural school directors that the compulsory attendance laws would be leniently executed. Since the farmers' vote is responsible for the incumbency of superintendents it is readily seen why they must be cautious in exercising their duties in this direction. ${ }^{\prime \prime 0}$ Elected officials could not help but be aware of the potential cost of enforcing school attendance laws. Access to education remained a problem for farm children, and one that received far less attention than in urban settings.

The reasons for lax enforcement were complex. First, legislators realized that farm families desperately needed their children's labor and were reluctant to threaten the health of the farm economy. And as John Gillette suggested, doing so might threaten their continued careers as public officials as well. Also, legislators and reformers were ambivalent about the impact of farm work on the nation's children. Most Americans embraced industry and hard work as character building. Could farm work, then, be completely wrong? Those concerned with child labor often criticized urban children for their lack of industry. As Gillette commented, "It is one of the recognized defects of city life that there is nothing at which to set the boys outside of school hours and in vacation periods. Idleness and idle habits, bad associations, and irregular wayward tendencies are the familiar fruits of the situation." Gillette did not approve of parents who worked their twelve-year-old sons as if they were men, but at the same time he could see the moral value of a reasonable amount of farm work for children."

Richard C. Barrett, who was elected as Iowa's state superintendent of schools in 1900, echoed many of the same sentiments. In his opinion, the farm itself was, in many ways, a school. "Nowhere on earth has a child such advantages for elementary education as upon a good farm, where he is trained to love work and to put his brains to work. The best taught school

40. John M. Gillette, "Rural Child Labor," Child Labor Bulletin 1 (June 1912), 160. 41. Ibid., 154-55. 
in a densely populated city can never equal in educative value the life upon a good farm intelligently managed." According to Barrett, farm work trained the body and the brain, but more importantly, improved the character of the child, a sentiment with which many farm parents would have agreed. "The child on the farm is made responsible for something, for some work, for some care-taking, and out of this responsibility grow trustworthiness, habits of work, and a feeling of personal power in all the essential elements of character." Barrett had few reservations about the quality of childlife on Iowa's farms, and those few, he believed, could be easily remedied by properly managed rural schools. In turn, he believed that properly managed rural schools would keep Iowa's farm children on the farm and away from the evils of the growing cities. ${ }^{42}$

The United States Children's Bureau found many of the same values in childlife on the farm. While the bureau generally condemned urban child labor, as well as many types of child labor on farms, it also applauded the values learned through appropriate levels of child labor in agriculture. "Children who do a reasonable amount of farm work, suited to their years and under the supervision of their parents, are fortunate. Such work inculcates habits of industry and develops family solidarity, both desirable objectives in any system of child training. ${ }^{\prime \prime 3}$ Farm life, unlike most urban occupations, allowed parents and children to work together as a single productive unit. In the best cases, this might enable all family members to experience a real sense of belonging and accomplishment. As Frances Olsen Day, who was raised on a farm near Dixon, reminisced, "There was plenty of hard work for everyone but there was a satisfaction even to a child of knowing that ones efforts were needed in the general scheme of things. That even the small daily chores faithfully done made life pleasant for us all and what greater reward can one wish for than to feel you have done your duty?"14

42. State of Iowa, Department of Public Instruction, Hand-Book for Iowa Schools, 1900 (Des Moines, 1900), 187. See also Baldwin et al., Farm Children, 295-96.

43. Nettie McGill, U.S. Department of Labor, Children's Bureau, Children in Agriculture, Bureau Publication No. 187 (Washington, DC, 1929), 42.

44. Frances Olsen Day, typescript reminiscence, "More About Life on the Prairie," SHSI, 11. 


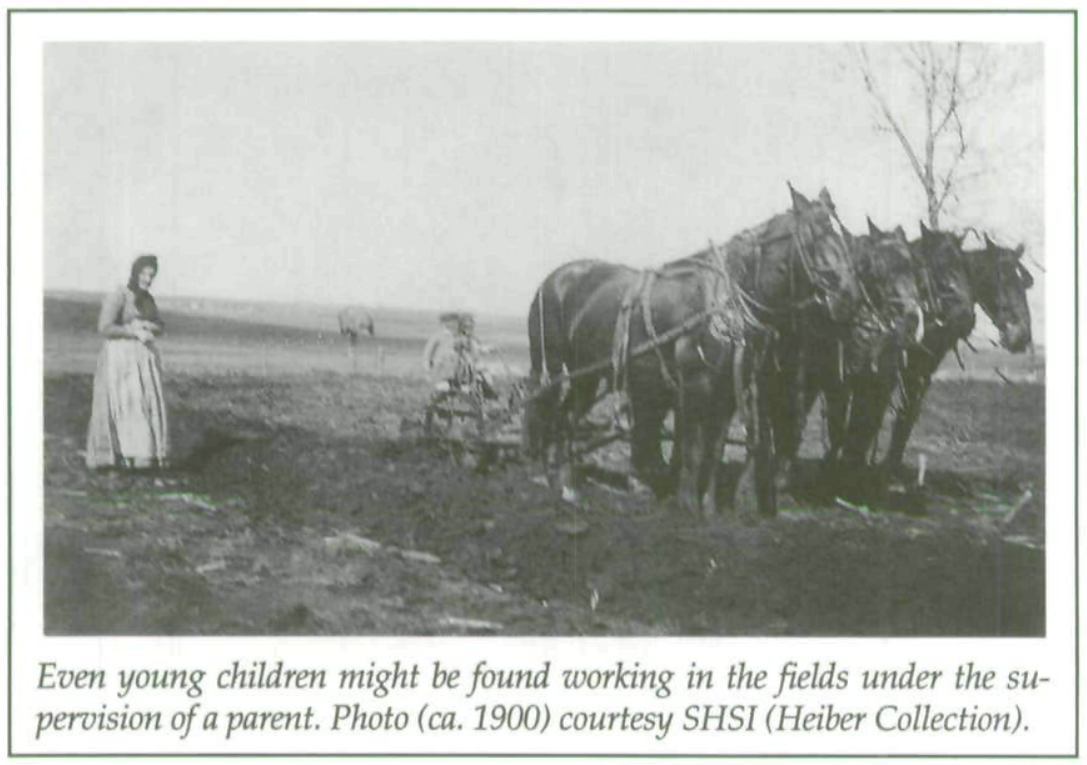

Whether youngsters actually felt this while working in the field on a ninety-degree day, or only realized this as adults in retrospect, it was a sentiment that reformers could happily and easily endorse..$^{45}$

Some commentators went on to wholeheartedly endorse child labor on farms. Charles Galpin, professor of agricultural economics at the University of Wisconsin, provided a positively rosy description of the social value of a rural childhood.

The labor of the child on the farm in America, with some few localized exceptions, has about it a minimum of child-labor features dangerous to the child and to society. Work in the fresh open air, attended with great variety of movement both from place to place and task to task, has none of the hazards of mines and factories to the growing body and soul.... The open country is a large mold, and the child's nature fits the mold. ... The farm-bred child . . . is the contribution of rural life to the human stock of society.

45. Liahna Babener argues that those who were raised on the midwestern farming frontier, despite any protestations to the contrary, in fact held a great deal of animosity against the circumstances of their upbringing. Babener would argue that Day's recollections had been inaccurately colored by time. I would argue, as did reformers at the time, that there was a kernel of truth in Day's assertion. Babener, "Bitter Nostalgia," 302. 


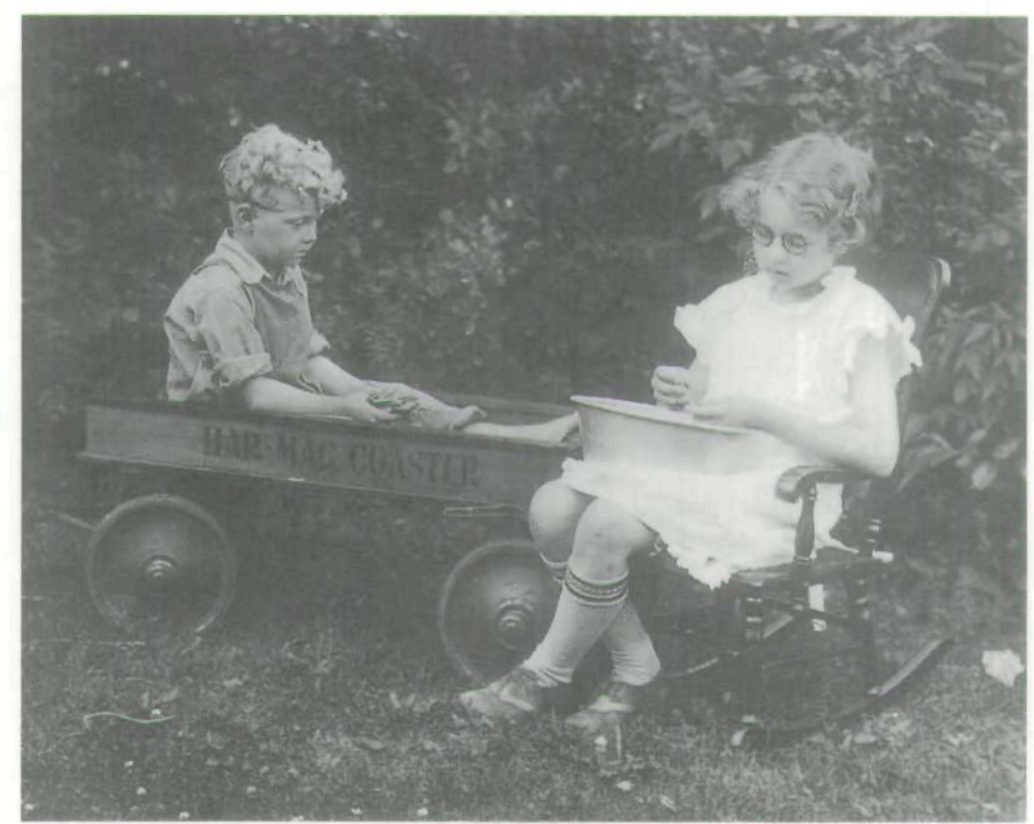

Shelling peas in the open air might occupy a summer's afternoon. Photo courtesy SHSI (Rickels Collection).

From Galpin's point of view, work could be defined as either healthy or unhealthy, and farm labor clearly fell into the healthy category since it provided vigorous exercise in the open air. ${ }^{46}$ While few were as enthusiastic about the benefits of farm labor as he was, few completely opposed it either. The key to the matter was to define how much work was too much, something that reformers found difficult to do. When the reviews were so mixed, it was hard to take a firm stand against what was common practice on hundreds of thousands of the nation's farms.

46. Charles Josiah Galpin, Rural Life (New York, 1918), 120-21. Linda Borish's research on farm women and health shows that many middle-class nineteenthcentury Americans believed that farm labor and farm living meant better health for farm females as a result of exposure to fresh air and regular exercise. Presumably the same logic applied to farm children. Linda Borish, "Farm Females, Fitness, and the Ideology of Physical Health in Antebellum New England," Agricultural History 64 (1990), 17-21. 
REFORMERS may have tempered their criticism as well because they perceived rural life as superior to urban life. Even as America was moving to the city, many still believed that the countryside had much to offer the nation's youth. Reformers valued education, but they also valued a love of nature, outdoor pursuits, and time spent in close contact with parents. As diaries and memoirs attest, life on farms was not without its compensations. Children lived in close contact with nature and relished the sights, sounds, and smells that surrounded them. As Louisa Boyland reflected in later life, "the hill sides abounded with flowers, dutch mans breeches, spring beauties, Indian paint-brushes \& many others. What joy we had roaming those hills \& woods." Frances Olsen Day, who lived on the prairie but visited the woods, also remembered the joy of exploring the forest, gathering nuts, berries, and wild fruit. "The woods were a wonderful change from the endless grass of the prairie and we entered a different world there." ${ }^{\prime 47}$

Children found much to interest them too in the barns and business of the farm. Mollie Krutza's strict parents did not allow her to play in the outbuildings. Her cousins, however, had more indulgent parents. She remembered that "they were lots of fun. They were allowed to do things that were forbidden at our house. . . . sliding down hay-stacks and jumping from the barn loft." ${ }^{\prime 8}$ The annual arrival of the threshing machine and crew thrilled Bruce Bliven, who grew up near Emmettsburg, and he loved to make "daring leap[s]" into the haymow. As a small child, Louisa Boylan also eagerly anticipated threshing time. "Those huge straw piles were our delight. What fun to climb to the top and slide down, dig caves into the sides and play keep house using pumpkins for children which we would dress in our old petticoats." The cornfields provided diversions as well. "Sometimes we got into the corn field and picked ears that had long silks and played they were our babies. That was cut short

47. Louisa Sophia H. Gelhorn Boylan, "My Life Story," manuscript reminiscence, 4, SHSI; Frances Olsen Day, "Pioneering," typescript reminiscence, 2, SHSI.

48. Krutza, "Memories of Childhood," 4.

49. Bruce Bliven, "A Prairie Boyhood," Palimpsest 49 (1968), 324, 326-27. 
when the folks found it out as the corn was too green to pick." ${ }^{150}$ For the imaginative child (and farm children needed to be imaginative), the farm was not just a workplace but also a playground.

Descriptions of the joys of farm life appear not only in memoirs, but also in contemporary accounts. In a letter to the children's magazine American Young Folks, ten-year-old Olive Everts of Discord, Iowa, summed up both the benefits and the disadvantages of a working childhood on a family farm.

We are having our vacation, now, in our school. My little sister and I are enjoying ourselves very much. Sometimes we go to the grove and hear the little birds sing and watch the little fish swim in the creek, and the squirrels, as they play around; and sometimes we go down to the hay field and watch the men put up hay, which we think is nice fun; and then again Ma makes us stay in the house and wipe dishes, and do chores, which we think is not quite so funny. Every night I take a ride if I like. It seems that we enjoy ourselves more than the little children that live in town. ${ }^{51}$

Balancing the weight of her chores against the natural advantages of the farm, Everts found her life satisfactory.

Henry C. Taylor, who grew up on an Iowa farm and eventually became a professor at Iowa State University, had much to say in his memoirs about the value of a farm childhood. For him, the compensations came most importantly in the form of time spent at his father's side, learning the art and craft of agriculture. This education began at an early age.

My first memory of his training was when I was two years old. He took me with him to the field and had me stand and watch him at work while he was making some repairs on a reaping machine. He always seemed to like to have me with him, even when I was too small to help, and I have no memory of his ever indicating that I was in his way. If he were making a repair at night, he would have me hold the lantern for him and would say, 'You hold the lantern so that you can see, then I can see..$^{52}$

50. Boylan, "My Life Story," 18.

51. Olive Everts, “Our Post Office," American Young Folks 5 (September 1879), 139.

52. Henry C. Taylor, Tarpleywick: A Century of Iowa Farming (Ames, 1970), 80. 
From the age of two onwards, Henry Taylor learned the family business from his father. From mending machines to plowing fields to shearing sheep, he was experiencing what reformers feared urban children would rarely experience: a practical education gained by working side by side with a parent through the seasons and the years. For Henry Taylor, it was a valuable education not only in agriculture, but also in life skills. His father was his first and best teacher, and the one he emulated in later life.

CHILDREN'S LIVES on Iowa's farms were a mixed story of both the good in rural life as well as its deprivations. It was not being a farmer's daughter or son, as such, that determined the quality of life for young people growing up on Iowa's farms. Not all farms, or all parents, were alike. What could make life difficult were the characteristics of individual farms and families. Those who lived on farms in the early stages of development often faced greater difficulties because of the unsure footing of their parents' enterprises and the necessity of subduing raw, untamed land. Those whose families were chronically poor, of course, suffered proportionally greater workloads and privations. Older children in very large families might find themselves overworked, caring for the farm and caring for their younger siblings. But too small a family might mean that children could not keep up with the demands of the farm, no matter how hard they worked. It is no wonder that farm families tended to be larger than rural, nonfarm families and those in urban areas. It is also no wonder that increasing numbers of young people chose to leave the countryside and seek their fortunes in America's growing cities. ${ }^{53}$ As those young people left behind the pain of an old-fashioned, working childhood, however, they also left behind its pleasures, taking corncob dolls, haystack slides, and berrying in the woods along with long, hot hours of plowing, planting, and weeding. The better educated, more carefully

53. Mary Neth cites surveys of farm-raised youth to show that many desired to leave agriculture because of discontent with the demands of unpaid labor on their parents' farms. Mary Neth, "Leisure and Generational Change: Farm Youths in the Midwest, 1910-1940," Agricultural History 67 (1993),182-83. 
sheltered childhood advocated by urban, middle-class reformers came at the cost of childhoods spent in the sun and wind, working and learning beside parents.

In turn-of-the-century Iowa, farm children lived lives that followed both old and new paths. Like their parents and grandparents before them, they contributed to the family farm and were an integral part of the agricultural economy. Without their labors, many family farms would have ceased to be. Increasingly, however, their parents sent them to school, an act that had the potential to bring profound change into their lives. A practical education in agricultural labor prepared farm children to one day run farms themselves. An education in a rural school, followed by attendance at a high school, might prepare a child for an alternative, non-agricultural occupation. This, too, might help to explain reformers' hesitation to enforce more strictly laws that would have required farm children to attend school. As much as they wanted children to be educated, they could hardly imagine, nor did they desire, a world in which the majority of farmers' children did not return to the farm. What reformers wanted was a world in which children benefited from the virtues of both the farm and the urbanized world, where they would experience a healthy level of work and close relationships with their parents as well as a well-rounded education. Rural families and reformers could only hope that the elimination of the worst elements of a rural childhood would not come at the cost of the best that world had to offer. 
Copyright of Annals of Iowa is the property of State of Iowa, by \& through the State Historical Society of Iowa and its content may not be copied or emailed to multiple sites or posted to a listserv without the copyright holder's express written permission. However, users may print, download, or email articles for individual use. 